\title{
Підготовка наукових кадрів вищої кваліфікації зі спортивної медицини, лікувальної фізкультури та фізичної реабілітації в Україні
}

\author{
В. В. Клапчук
}

Запорізький національний технічний університет, Запоріжжя, Україна

Науковцями України за всі роки існування колишнього СРСР з лікувальної фрізкультури в галузі медичних наук було захищено лише три докторські дисертації (В. М. Максимова, Харків; Г. В. Полеся, Київ; В. В. Клапчук, Ялта) та одна докторська дисертація в галузі біологічних наук (В. П. Мурза, Київ). Окремі науковці, відомі як фрахівці з лікувальної фрізкультури, захищали дисертації з інших наукових спеціальностей. Це, зокрема, В. А. Блях, О. В. Кочаровська, Г. Й. Красносельський, В. Т. Стовбун (Київ), Я. Й. Камінський, О. Ю. Штеренгерц, В. С. Соколовський (Одеса), К. Й. Муха, Т. О. Третилова (Львів), Т. Н. Нікітін (Слов'янськ). За роки незалежності українські науковці докторські дисертації з лікувальної фрізкультури не захищали.

На противагу цьому, зі спортивної медицини та лікарського контролю в оздоровчій фрізичній культурі докторських дисертацій було дев'ять. Зокрема, за роки незалежності в Україні захищено такі докторські дисертації в галузі медичних наук за спеціальністю 14.01.24 - лікувальна фрізкультура та спортивна медицина: Віктор Васильович Абрамов (1992; «Становлення фрункції ендокринної і кардіореспіраторної систем спортсменок пубертатного віку»), Валентина Андріївна Шаповалова (1993; «Функціональна і фрізична підготовленість дітей шкільного віку в онтогенезі: діагностика і оздоровлення немедикаментозними засобами»), Володимир Миколайович Литвинов (1994; «Корекція психофрізичного стану спортсменів при часовій кліматичній дезадаптації та напруженому фрізичному тренуванні»), Олена Леонідівна Єрьоміна (1994; «Клініко-фрізіологічне обгрунтування дифреренційованих режимів фрізичних тренувань»), Олена Євгеніївна Дороффєєва (2006; «Механізми адаптації, рання діагностика та корекція їх порушень у спорті вищих досягнень»), Євген Леонідович Михалюк (2007; «Діагностика граничних та патологічних станів при крайніх фрізичних навантаженнях в олімпійському та професійному спорті»), Олександр Петрович Романчук (2007; «Санотипування: об'єктивна експертиза функціональної достатності організму в умовах спортивного вдосконалення»), Віктор Петрович Корж (2010; «Медико-біологічне забезпечення спортсменів вищої кваліфікації»), Олег Борисович Неханевич (2016; «Особливості лікарського контролю за особами з ознаками дисплазії сполучної тканини на етапах відбору та спортивного вдосконалення»).

Починаючи з 1994 р., захисти зазначених дисертацій проводились у спеціалізованій вченій раді при Дніпропетровській державній медичній академії, яка в Україні з 1993 р. залишається єдиною. Спочатку вона була самостійною (голова - професор В. В. Клапчук), а з 2001 р. після удосконалення ВАК України мережі спеціалізованих вчених рад - об'єднаною.

Щодо підготовки наукових кадрів вищої кваліфрікації немедичними працівниками слід зазначити, що, на жаль, з 1975 р. Міністерство охорони здоров'я колишнього СРСР вимагало, щоб «біля ліжка хворого був тільки медичний працівник». Одночасно ВАК СРСР заборонив захисти дисертацій з лікувальної фрізкультури в галузі педагогічних та біологічних наук. Але у самостійній Україні у галузі наук з фрізичного виховання та 
спорту було введено спеціальність «Фізична реабілітація».

Фізична реабілітація як наукова спеціальність була заснована завдяки зусиллям наукової громадськості, вчених рад, ректорів вищих навчальних закладів фрізичного виховання і спорту. 32000 р. розпочалася підготовка вищих науково-педагогічних кадрів через аспірантуру та докторантуру з цієї спеціальності. Це забезпечило підготовку кадрів для наукової і практичної роботи з фрізичної реабілітації. Натепер серед захищених дисертацій за спеціальністю 24.00 .03 - «Фізична реабілітація» $\epsilon$ ряд давно очікуваних змістовних і корисних для практики докторських, захищених у спеціалізованих вчених радах Національного університету фрізичного виховання і спорту України та Львівського університету фрізичної культури в галузі наук з фрізичного виховання та спорту. Це Наталія Іванівна Соколова (2006; «Превентивна фрізична реабілітація як стратегія профрілактики хронічних соматичних захворювань»), Ольга Ярославівна Андрійчук (2013; «Теоретико-методичні основи фрізичної реабілітації хворих на гонартроз»), Олена Борисівна Лазарева (2013; «Теоретикометодичні основи фрізичної реабілітації при хірургічному лікуванні вертеброгенних попереково-крижових синдромів»), Еліна Володимирівна
Макарова (2013; «Фізична реабілітація в загальній структурі соціальної адаптації студентів 3 iнвалідністю»), Наталія Євгенівна Нестерчук (2015; «Теоретико-методичні основи фрізичної реабілітації дітей з вродженою клишоногістю»), Олексій Костянтинович Ніканоров (2016; «Теоретикометодичні основи фрізичної реабілітації спортсменів з пошкодженням передньої хрестоподібної зв'язки колінного суглоба (на прикладі ігрових видів спорту), Ірина Олександрівна Жарова (2016; «Теоретико-методичні основи орізичної реабілітації при первинному екзогенно-конституціональному ожирінні в підлітків»), Світлана Станіславівна Люгайло (2017; «Теоретикометодичні основи фрізичної реабілітації при дисфункціях соматичних систем у юних спортсменів в процесі багаторічної підготовки»). Наталія Олександрівна Бєлікова захистила докторську дисертацію у галузі педагогічних наук за спеціальністю «Теорія і методика професійної освіти» (2012; «Теоретичні і методичні засади підготовки майбутніх фрахівців з фрізичної реабілітації до здоров'язберігаючої діяльності»). У галузі біологічних наук за спеціальністю «Медична та біологічна інформатика і кібернетика» Дмитро Вікторович Вакуленко (2016) захистив докторську дисертацію на тему «Інформаційна система медичної (фрізичної) реабілітації».

Надійшла 12.09.2017 